\title{
Toward an Integral Human Development Ethics
}

\author{
LORI KELEHER* \\ New Mexico State University (United States of America) \\ lkeleher@nmsu.edu
}

\begin{abstract}
In this paper, I provide an introduction to development ethics and make some observations about integral human development. I argue that although there is very little dialogue between these two traditions, they have a lot of common ground, and can helpfully inform one another. International development ethics is a largely secular field concerned with ethical reflection on the ends and means of development. I discuss four levels of ethical reflection: (1) meta-ethical, (2) normative, (3) practical, or applied, and (4) personal or integral. The first three of these levels are well established in philosophical ethics. I introduce the fourth with the hope of encouraging more discussion of how individuals engaged in the theory and practice of development ethics ought to navigate the various spheres of their own lives. This last stage of ethical reflection and action can benefit greatly from work done in integral human development. Integral human development is integral in at least two ways: (1) development is not simply economic development, but development the whole person, including social, political, creative, spiritual, etc., and (2) development is the development of every person, whether the person is a marginalize peasant or a powerful elite. I explain why this second way of integration is both less discussed and more radical than the first.
\end{abstract}

Keywords: Development Ethics, Integral Human Development, Populorum progressio, Louis-Joseph Lebret, Denis Goulet.

\section{Hacia una ética del desarrollo bumano integral}

\begin{abstract}
Resumen
En este articulo, ofrezco una introducción a la ética del desarrollo y hago algunas observaciones sobre el desarrollo bumano integral. Sostengo que, aunque bay muy poco diálogo entre estas dos tradiciones, tienen mucho terreno común y pueden ayudarse mutuamente. La ética del desarrollo internacional es un campo ampliamente secular que se ocupa de la reflexión ética sobre los fines y los medios de desarrollo. Discuto cuatro niveles de reflexión ética: (1) meta-ético, (2) normativo, (3) práctico, o aplicado, y (4) personal o integral. Los tres primeros de estos niveles están bien establecidos en la ética filosófica. Presento el cuarto con la esperanza de fomentar una mayor discusión sobre cómo los individuos involucrados en la teoría y la práctica de la ética del desarrollo deben navegar por las diversas esferas de sus propias vidas. Esta última etapa de reflexión y acción ética puede beneficiarse enormemente del trabajo realizado en el desarrollo bumano integral. El desarrollo bumano integral es integral en al menos dos maneras: (1) el desarrollo no es simplemente desarrollo económico, sino el desarrollo de toda la persona, incluyendo social, político, creativo, espiritual, etc., y (2) el desarrollo es el desarrollo de cada persona, sea la persona un campesino marginado o una de la ponderosa elite. Explico por qué esta segunda forma de integración es menos discutida y más radical que la primera.
\end{abstract}

Palabras clave: Ética del desarrollo, Desarrollo Humano Integral, Populorum progressio, Louis-Joseph Lebret, Denis Goulet.

* Holds a PhD in philosophy and is an associate professor at New Mexico State University. She is the author of "Empowerment and international development" (under Loretta Wills Keleher), 2007 (available for free download here: http://drum.lib.umd.edu/handle/1903/7584). With Stacy J. Kosko she is co-editor of Agency and Democracy in Development Ethics, Forthcoming, Cambridge University Press, 2017. With Jay Drydyk she is the co-editor of the Routledge Handbook to Development Ethics, Forthcoming, Francis and Taylor, 2018. 
Louis-Joseph Lebret (1897-1966) was a French economist and social planner who established an influential Research Center: Economy and Humanism in Marseille, 1941. Lebret is widely recognized as a pioneer in the field that has come to be known as development ethics. Development ethics is an interdisciplinary -and largely secular- field of study concerned with the ethical reflection on the means and ends of development. LouisJoseph Lebret was also a Dominican priest who was identified by Pope Paul VI as one of the principle investigators of the very influential 1967 encyclical Populorum Progresio (or Development of Peoples) (Cosmao, 1970: 62). Populorum Progresio is the foundational text for those working with integral human development. Thus, Lebret is an ancestor of both contemporary development ethics and contemporary integral human development. This common ancestry has led to common priorities and themes within both traditions (for example, a focus on human-centered development). Yet, there is little interaction between those who identify as working within development ethics and those who identify as working within integral human development.

Indeed, many career development ethicists have never even heard of integral human development and many of those most engaged in promoting integral human development have never heard the phrase development ethics $^{1}$. As a consequence, work done in development ethics is largely unknown among those working within integral human development and vice versa. To some extent this is understandable because the two are in some ways different projects with different -albeit, complementary- purposes, so it is both understandable and necessary that different discussions take place. At the same time, there is considerable overlap between the two traditions such that the scope of each tradition might be represented as one circle in a Venn diagram of overlapping sets. More importantly, those working in each field can learn a lot from the other.

In this essay, I provide a brief introduction of development ethics as a field of study, before making a few observations about integral human development and how the two traditions overlap. My hope in identifying this existing common ground is to encourage communication and collaboration between those working in each tradition. I believe that such communication is too often avoided because there are suspicions on both sides

\footnotetext{
1 Noteworthy exceptions to this observation include recent efforts by scholars brought together at the University of Notre Dame in the United States. See for example, Séverine Deneulin.
} 
of a religious vs. secular divide, but that collaboration would prove beneficial to people working within both traditions and to those lives such work seeks to improve. Thus, those serious about improving human well being will be interested in learning from work done in both development ethics and integral human development. Furthermore, can participate in both traditions from either a religious or a secular standpoint.

The paper is organized as follows: I provide a very brief history of international development before introducing development ethics as a field of study concerned with the ethical reflection on the ends and means of development. I discuss four levels of ethical reflection: (1) meta-ethical, (2) normative, (3) practical, or applied, and (4) personal or integral. The first three of these levels are well established in philosophical ethics. I introduce the fourth with the hope of encouraging more discussion of how individuals engaged in the theory and practice of development ethics ought to navigate the various spheres of their own lives. I then turn my focus to integral human development: I observe that integral human development is integral in at least two ways: (1) development is not simply economic development, but development the whole person, including social, political, creative, spiritual, etc., and (2) development is the development of every person, whether the person is a marginalize peasant or a powerful elite. I explain why this second way of integration is both less discussed and more radical than the first. Finally, as a corollary of (2), all people -secular and Catholic- can (and should) practice integral human development. Given the existing common ground between the two traditions, and the fact that development ethics provides a space where useful tools and insights that can inform and facilitate the practice of integral human development, I hope that this essay can be a first step towards integral human development ethics.

\section{DEVELOPMENT ETHICS: A VERY BRIEF HISTORY}

The middle of the $20^{\text {th }}$ century saw the end of the Second World War followed by the reconstruction of Europe made possible by the Marshall Plan aid and by the beginning of post-colonial independent nations seeking aid. Since the 1950s international investments, loans, and interventions have been made in accordance with growth-oriented economic theories that seek to "develop" less developed countries (LDCs) by generating and sustaining an increase in the country's gross national product (GNP). Many who work to promote GNP growth do so with the hope and expectation that doing so will bring about a decrease in economic poverty. The gains in country's GNP are expected either to "trickle down" to the poor in the forms of jobs and other economic opportunities or to create the 
environment required for a wide distribution of social and material goods, which in turn would decrease poverty by improving the economic well being of the poor. However, although many less developed countries realized their GNP growth rate targets in the 1950s 60s, and 70s, the lives of the vast majority of poor people in these countries remained largely unchanged and in many cases got even worse. In the 80 s and early 90 s, the majority of less developed countries stopped meeting their GNP growth rate targets, and in many cases, especially in Africa, GNP growth rates turned negative. International aid and development programs did not only fail to increase economic growth, they also failed to improve the lives of human beings. Poor countries often sacrificed state social and economic redistribution programs as they struggled to repay mounting foreign debts. The needs of the poor people and efforts to promote human well being were seen as secondary to growth in the national economy. As Paul Streeten observed "it is development itself that interferes with human development" (1994: 13).

A great deal of criticism of development policies arose in response to these failures. One influential group, the Post Development School, advocates rejecting not only development programs, but also the concept 'development' altogether (Escobar, 1984, 1995, 2000, 2007; Esteva 1985, 1987, 1998; Sengupta, 2018; Ziai, 2004, 2007, 2013). Gustavo Esteva wrote "The time has come to recognize development itself as a malignant myth...a huge, irresponsible experiment that, in the experience of a world-majority, failed miserably" (1985: 78). Others, not willing to throw out the proverbial baby of development with the bath water of failed policies, began to seek alternative approaches to GNP growth focused development (Nussbaum 1988; Seers, 1969; Streeten, 1981; Sen, 1979, 1985).

It is in this climate of disastrous development interventions and schemes focused on economic growth at the cost of a forgotten poor that the field of development ethics emerged. Denis Goulet, who is often regarded as the "father" of development ethics (Dower, 2008: 184; Wilber \& Dutt, 2010), recognized that many efforts made in the name of development were deeply problematic. Yet he resisted the Post Development School's call to dispense with the concept of development altogether. Instead, Goulet introduced a distinction between undesirable anti-development, which ought to be avoided, and worthwhile authentic development, which ought to be promoted (1977: 189. 215). For Goulet, genuine progress entails more than economic growth, it requires that people become "more human." On this view, "Societies are more human, or more developed, not when men and women 'bave more' but when they are enabled to 'be more.' The main criterion of development is not increased production 
or material well being but qualitative human enrichment" (Goulet, 1995: 6-7).

The insight that authentic development is development that results in individuals and societies becoming more human has been embraced by the vast majority development ethicists and is reflected in the phrase human-centered development. Human-centered development is promoted by the human development capability approach and the Human Development Index used by the United Nations Development Program, and many others. If Goulet is the father of development ethics, then his mentor, who Goulet credits with this insight, must be the grandfather of development ethics. Goulet's mentor was Joseph Lebret. Thus, it should not be surprising that both Goulet's approach to development ethics, and the integral human development approach discussed in Populorum Progresio are focused on human-centered development.

In some ways, development ethics as a field of study is larger than either Goulet's approach to development ethics, or integral human development. As a field of study it is not and cannot be committed to any particular set of values, including the idea of human centered development. This is because development ethics is not a monolithic view, but field of study, an intellectual space for the exchange of ideas that can and must accommodate various ideas about what makes for ethical development. Hence, while integral human development and Goulet's own views are committed to human-centered development, the field of development ethics must be open to the discussion of other possibilities. This is true even though the vast majority of development ethicists in fact do subscribe to human-centered development. Discussing other possibilities and submitting our own positions to scrutiny allows us to be conscious of and avoid the danger of what Goulet calls "latent and unavowed philosophical positions" (1995: 18).

\section{DEVELOPMENT ETHICS AS ETHICAL REFLECTION ON THE ENDS AND} MEANS OF DEVELOPMENT

The nature and scope of development ethics has been defined as ethical reflection on the ends and means of development ${ }^{2}$. When we consider

2 Many scholars have directly engaged questions about the scope and nature of development ethics (including Crocker, 1991, 2008; Dower, 2008; Drydyk, 2011, 2016; Drydyk and Keleher 2018; Esquith and Gifford, 2010; Gasper, 2004; Goulet, 1971, 1995 , 2006; Keleher, 2017, Schwenke, 2009; and many others). Analyzing these contributions is beyond the scope of this essay, but I consider my present contribution as complementary, not in competition with these existing efforts. 
the ends of development, we ask: what are we ultimately trying to accomplish? It should not be surprising that this question of the ultimate end of development is debated within development ethics. Candidates for this final end include not only the "human ascent" that Lebret and Goulet championed, but also economic growth, modernization, basic needs, happiness, well-being, freedom, empowerment, agency, capabilities (or opportunities), democratic participation as well as many others.

As development ethicists, we reflect on these final goals, why we (might) value them, whether we ought to pursue them, and if so how. For example, as mentioned above, many consider raising a less developed country's economic (GNP) growth to be the final end of development, let's assume that this is our final goal ${ }^{3}$. Why might we value a high or growing GNP? A high GNP does not necessarily make people better off. GNP is an aggregate measurement that does not tell us anything about how wealth is distributed, and therefor cannot account for inequalities of wealth within a country. We can easily imagine two needy people with comparable quality of life; one living in a country with a high GNP, and the other living in a country with a low GNP. Some economists may argue that those living in counties with high GNPs are more likely to have a better quality of life. Others may urge us to consider GNP growth plus another economic measurement (gini co-efficient) that aims to reflect the distribution of wealth within a country. But even if grant an increased likelihood of a higher quality of life and a more equitable distribution of wealth, it is still true that wealth cannot ensure quality of life. Imagine a person who has wealth, must spend the majority of it on expensive medical treatments, or a woman who has a relative opulent lifestyle, but is not allowed to learn to read, has little or no say in what she wears, or where she goes, or who she marries (and by no co-incidence with whom she has sexual relations). There is a real sense in which this woman does not enjoy a suitable quality of life. It seems that a high or growing GNP, at best reflects a likelihood that we will have access to wealth and that wealth at best reflects a likelihood that we will have a better quality of life, and even then, we have a better quality of life not because we have wealth, but because of what we are able to do with it. Thus, GNP and wealth are at best instrumentally valuable. Our reflections on GNP as an end of development reveal that there is nothing intrinsically valuable about having a high or growing GNP. Once

3 For an in depth evaluation of the ends and means of the economic growth approach and the capability approach to human development see Keleher, 2007, Chapters 1 and 2. For a very brief evaluation of the final ends and means of the (1) economic growth, (2) utilitarian approach, (3) contemporary happiness approaches, and (4) the capability approach to human development; see Keleher, 2014. 
we understand that wealth is merely instrumentally valuable, we might still decide to pursue it, but with the understand that we are doing so as a means that can at best increase the likelihood of securing what we actually value. Although the field of development ethics must remain open to reflecting upon and discussing various candidates for the final end of development, these reflections strongly suggest that Lebret and Goulet are correct, and that improving the lives of human beings is an intrinsically valuable end of development. (It is not easy to say that improving the lives of human beings is the only end of development, as nonhuman lives and the rest of the environment are also valuable).

Once we identify the final goal of development we must also ask what are the means for achieving this goal? How do we ensure that they are effective and thereby ethical? Do we invest in businesses, open markets, introduce technology, work to provide healthcare or education or political/legal protections? Once we identify the means, these become intermediate goals, which are steps towards our final goal. So we must then ask what are the effective and ethical means to the means? In other words, how do we achieve the intermediate goals without losing sight of the final goal? Do we offer micro-lending programs to women-run businesses, incentivize the development and introduction of new technology for sustainable energy, provide healthcare subsidies for the least well-off, create bilingual education programs to help linguistic minorities better integrate into the economy and society, work to pass legislation that ensures the recognition of migrant families? In considering these issues we may identify more intermediate goals and more means of achieving them. At each step of the development process we face the challenge of considering the ethical dimensions of our actions.

Suppose we take as our final goal to develop a more buman life for each person and a more human society for all. If this is our goal, then it is not good to promote access to markets if doing so will mean exploiting workers and violating human rights, because exploitation will not make us more human as individuals or as a society (even if increased access to markets increases GNP growth and generate wealth). When considering the means we must also consider who is responsible for implementing, overseeing, and funding local and international development projects, and the short-term goals we hope will allow us to achieve our higher order goals. We must ask questions about how the outsiders of a culture can work with insiders in a truly human way (Crocker, 2006). Thus, there are countless areas for ethical reflection about how to understand and implement the ends and means of development. 
There are different levels of ethical reflection and discourse that are useful in engaging the ends and means of development. Philosophers often identify three distinct areas or levels: meta-ethics, normative ethics, and practical or applied ethics (Cavalier, 2003; Fieser, 2017). In addition to these three well established domains of ethical reflection, I submit that those working in development will find it fruitful to consider a fourth dimension: personal or integral ethics. I explain each of these levels below.

- Meta-ethics considers higher order questions of value, the meaning of concepts, and any universal truths about ethics including: What is the good? What is the good life or the good society? Is freedom intrinsically valuable? Are there moral duties? What is development (vs. anti-development)? What does it mean to be more or less human? How, if at all, is ethics related to God? And many other metaphysical issues are discussed at this level.

- Normative ethics is concerned with the principles or other action guiding content or standards of moral behavior. Immanuel Kant's categorical imperative: "We ought never treat humanity whether in ourselves or another person merely as a means, but always as an end," and Jeremy Bentham's grounding of utilitarianism "We ought to approve or disapprove of every action according to the tendency it appears to have to augment or diminish the happiness of the party whose interest is in question" are two prominent examples of the sort of theories found at this level.

- Applied orpractical ethics considers more specific issues or realms of human action in a way that generates subject specific guidelines or positions on specific questions. For example, the realm of medical ethics, or the specific question of whether or not physicianassisted suicide is morally permissible. Likewise, agricultural ethics, or the specific question of whether or not it is morally permissible to use agrochemical inputs that generate higher yields, but undermine sustainability, and may have long-term implications for human health.

- Personal or integral ethics is the level at which we as individuals must consider the moral dimensions of our particular actions as an individual part of the various realms of life in which we participate. 
I make this addition to the standard list of three levels or domains of ethics because I think it is helpful to explicitly recognize that each of us must deliberately consider our own particular actions and how we integrate choices made in various spheres of our lives so that we can live with integrity. I believe discussion at this level has thus far been avoided because it would be unwise, even if it were not impossible, do try to develop an authoritative one-sizefits-all strategy to be used in navigating the moral dimensions of our particular actions as an individual part of the various realms of life in which we participate. At the same time, to simply say "it depends on the person and her situation" leaves the door wide open to a dangerous relativism. Published work at this level will be difficult and may be best approached by identifying what questions individuals should ask, rather than issuing ridged one-sizefits-all commands that must always be followed regardless of an individual's particular circumstances. Nevertheless, engaging in this level of ethical inquiry is of vital importance as it allows us to think critically about how we might integrate our understanding of reality with our daily behaviors. For example, we must consider not only whether or not physician-assisted suicide is morally permissible, but also our particular actions: how do I best help my terminally ill friend Alex who wants a physician's help to commit suicide? Or, consider an agro-economist who works for a large development firm that does not always seek to promote sustainability and yet personally believes that sustainability ought to be a priority in development interventions. How does she best integrate her beliefs? This fourth dimension has significant implications for human ascent.

Our considerations at each level can be secular or religious and will be influenced by insights generated at other levels. The higher order levels are ontologically prior in that beliefs held at higher levels tend to be more deeply held, and will therefore trump lower level beliefs when making decisions. But the higher order beliefs can still be shaped by experiences, including experiences of reasoning about lower order beliefs. Indeed, we are often provoked into sharpening our abstract, higher order beliefs by our concrete experiences Consider the following two examples of particular situations that provoke reflection on higher order beliefs, and eventually result in actions grounded in such beliefs:

1. Consider Alex, who wants a physician's help to commit suicide. How we try to help Alex might reflect the position that physician 
assisted suicide is not morally permissible, which might in turn be grounded in the idea that physician assisted suicide violates the categorical imperative because it uses the physician (or our own selves) as a means to ending our own suffering, which, finally is grounded in our higher order understanding that the good for human beings just is what Kant calls acting out of a good will.

2. Consider an agro-economist who personally prioritizes sustainability in development intervention, but works for a firm that does not always do so. ${ }^{4}$ How does she work at such a firm with integrity? She might decide to try to ensure that the projects on which she personally works are sustainable, or respectfully voice her opinion that unsustainable projects are anti-development when she has occasion to do so. In this way, her personal behavior will reflect her belief that promoting unsustainable agricultural practices in development is immoral, which might be grounded in a religious notion that all creation is sacred and that people have dominion over, that is are supposed to care for, the world, which may in turn be grounded in an understanding of the good as acting in accordance with God's will.

Note that in both examples, there are a number of ways in which a person might integrate their general moral beliefs with their particular actions. For example, depending on the context and details of the situation, it may make more sense for the agro-economist to quit her job, or to start a sustainability-working group within the firm, or to take some other course. The desirability and feasibility of these paths will depend on her particular options, responsibilities, and personal abilities. Thus, if we are going to be effective agents of development, then we need more attention paid to the particular challenges we each face at the individual or integral level, not because we can generate a one-size fits all system, but in order to cultivate our understand of moral issues and our ability to recognize and navigate unique situations.

Recognizing that each of us may find ourselves in unique situations, or that different people or groups in nearly identical situations may do best if they take different actions, or that different people may ground their ethical behavior in different (secular and religious) understandings of the

\footnotetext{
$4 \quad$ There are several situations people living in poverty regularly face in light of limited access to resources and opportunities. I choose to highlight an example of a person of privilege, who more likely to similar to those likely to read this article in the hope that the example is relatable to readers.
} 
good, does not entail moral relativism. We can allow for diversity of values and functions in individuals and for a healthy pluralism of ideas without opening the gates to relativism. As Pope John Paul II said "Peoples or nations too have a right to their full development, which ... should also include individual cultural identity... Not even the need for development can be used as an excuse for imposing on other's one's own way of life or own religious beliefs" (1987).

Development ethics provides an interdisciplinary and intellectual space for the reflection and analysis of our values, functions, and ideas in a rigorous and informed way that allows us to define a healthy pluralism and to reject unsupportable values, harmful functions, and false beliefs. This space is full of useful tools for ethical reflections as well as ideas that are the products of these reflections. (For example, the Human Development Index (HDI), is a multidimensional index that strives to measure what people can be and do. It has replaced GNP evaluations in the United Nations Development Program.) In reflecting on and making explicit the values that underpin these choices we recognize that development is an inherently value-laden process and not merely a positive science of mathematical equations. When we make decisions in development economics that result in the improvement of some lives, but not others, or even at the cost of others, we are making moral decisions. To choose not to recognize the ethical dimensions of economic enterprises is to make a moral choice. Normative aspects of economic development and the need for ethical reflection exist whether we recognize them or not.

Development ethicists work to understand the ethical aspects of development, including the ideas and policies we eventually reject, so that we can ultimately engage in authentic development and avoid anti-development. A noteworthy example of an attempt to identify authentic development is Jay Drydyk's list of "seven values of development" ((1) Wellbeing, (2) Equity/Equality, (3) Participation/agency/ empowerment, (4) Sustainability, (5) Human Rights, (6) Cultural Freedom, and (7) does not involve corruption), which he argues reflect authentic development, i.e., development that makes us more human (Drydyk, 2011, 2016). In other words, Drydyk's secular work in development ethics (which has shaped the forthcoming Routledge Handbook to Development Etbics, 2018) strives to bring about the same sort of development the same sort of development that is championed by Goulet, Lebret, and the integral human development of Pope Paul VI's Populorum Progressio. Thus, development ethics can helpfully inform those (secular and religious) working to advance integral human development. 


\section{INTEGRAL HUMAN DEVELOPMENT}

Pope Paul VI's most enduring encyclical, Populorum Progressio (1967) makes a valuable contribution to development ethics. Populorum Progressio and the notion of integral human development receive considerable attention from Church scholars. (John Paul II's Sollicitudo Rei Sociales and Benedict XVI's Caritas in Veritate, as well as the present issue of Veritas for which this essay is written, are all devoted to the theme of Populorum Progressio.) However, many working within development ethics have yet to study and therefore to fully appreciate this contribution. I suspect that this is because there is suspicion on both sides of a (perceived) secular - religious divide. Thus, many Catholics familiar with the encyclical typically discuss it only with other Catholics. Perhaps they assume that non-Catholics will fail to (fully) appreciate the encyclical. Likewise, many secular or non-Catholic development ethicists who have heard of the encyclical may hold a belief (whether it be conscious or opaque) that the wisdom of Populorum Progressio and integral human development is to be considered wisdom only if you are Catholic. Similarly, Catholic scholars may avoid the development ethics literature, because they assume it is full of incomplete theories (i.e., theories that are missing the divine piece of the puzzle). Yet, I believe that these two traditions have a lot to offer one another. I have already shown that those working in integral human development have good reasons to be interested in the methods, tools and ideas of development ethics. In the space remaining I make a few observations about integral human development, and how it can helpfully inform those working in development ethics.

According to Populorum Progressio: "Development cannot be limited to mere economic growth. In order to be authentic, it must be complete: integral, that is, it has to promote the good of every man and of the whole man" (14). Thus, integral human development holds that development that enables us to be more human must be integral in at least two ways. First development must be the development the whole person, not just the monetary or narrowly understood economic development, but also social, political, creative, spiritual, etc. This aspect of integral human development is captured well by the (secular) capability approach to human development, which is frequently advocated by development ethicists and understands poverty as a lack of opportunities to be and do things required for human flourishing (Sen, 1979, 1985, 2001; Nussbaum, 2001, 2011).

The second way in which integral human development is integral is that it requires the development of every person. Most seem to take this to mean that people working in development should seek to help every single poor person. But, integral human development is more radical than 
this interpretation can accommodate. Integral human development actually requires the development of every single person, whether that person is a marginalize peasant or a powerful elite. The philosophical underpinnings of integral human development requires not only that the poor are relieved of their poverty, but that the poor and the rich stand together in a relationship of solidarity as members of the human family. This solidarity is grounded in a mutual recognition of human dignity, which entails that all human beings are inherently valuable and deserve to flourish. From within such a relationship of recognition, it is clear to those who have an abundance of resources that they ought to use those resources for the good of the whole. As Paul VI wrote "This demands great generosity, much sacrifice and unceasing effort on the part of the rich" (1967). In this way, both the individual and society become more human. This focus on solidarity and development of all people is reflected in Goulet's understanding of authentic development.

It is clear from the above discussion that development ethics has a great deal to offer those who want to advance integral human development and vice versa. It is also obvious that both secular and religious people can benefit from and contribute to the open and pluralistic field of development ethics. Because integral human development was born from the larger tradition of the Catholic Church, it is less obvious that secular and religious people can practice integral human development. Yet, it follows from the core understand of integral human development that all people can and should so practice. Integral human development has deep roots within the Catholic Church, but its own philosophical structure requires that it go beyond the Church: "It is not just a matter of eliminating hunger, nor even of reducing poverty. The struggle against destitution, though urgent and necessary, is not enough. It is a question, rather of building a world where every man, no matter his race, religion, or nationality can live a fully human life" (Paul VI, 1967). The work done within integral human development, including but not limited to official documents of the Catholic Church can meaningfully enrich work in development ethics. I think integral human development holds special promise for enhancing the fourth level of ethical reflection discussed above, which is concerned with how individuals integrate their values and higher order beliefs as they navigate the moral issues encountered in particular circumstances.

Development ethics is an interdisciplinary field of study grounded in ethical reflection on the ends and means of development. As far as it offers perspectives on human development, work on integral human development is a part of development ethics. But development ethics must go 
beyond integral human development to analyze other ideas about development. Integral human development has been promoted and nurtured by the Catholic Church. Yet, even according to the Church's description, integral human development must go beyond the Church. Thus, secular and religious development ethicists should be encouraged to engage the integral human development tradition. However, integral human development must also either go beyond, what is typically seen as the scope of development or stretch development ethics to recognize human development as "building a world where very [person]... can live a fully human life." It is in this way that these two fields are related, but each has a distinct purpose. We should not be too surprised by the family resemblance shared these distinct traditions. After all, Louis-Joseph Lebret is a common ancestor. Although development ethics must go beyond integral human development and integral human development must go beyond development ethics. I believe there exists enough common ground to talk intelligently about and work toward the development of a subfield "integral human development ethics". Those working in this area would do well to take up the challenge of Denis Goulet: "to render the economy more human and to keep hope alive in the face of the seeming impossibility of achieving human development for all" (1997: 1160).

\section{REFERENCES}

-Catholic Church. (1967). Encyclical letter (Populorum progressio) of His Holiness Pope Paul VI. London: Catholic Truth Society.

-Catholic Church (1987). Encyclical letter (Sollicitudo Rei Socialis) of His Holiness Pope John Paul II. London: Catholic Truth Society.

-Catholic Church (2007). Encyclical letter (Caritas in Veritate) of His Holiness Pope Benedict XVI. London: Catholic Truth Society.

-Chenery, H. et. al. (1974). Redistribution with Growth. New York: Oxford University Press.

-Cosmao, V. (1970). Louis-Joseph Lebret, O.P. 1897-1966: From social action to the struggle for development. New Blackfriars, 51(587), 62-68.

-Crocker, D. A. (1991). Toward development ethics. World development, 19(5), 457483.

-Crocker, D. A. (2006). Insiders and outsides in international development. World Ethics, 5(1), 149-173.

-Crocker, D. A. (2008). Ethics of global development: Agency, capability, and deliberative democracy. New York: Cambridge University Press.

-Drydyk, J. (2016). Ethical Issues in Development. In J. Grugel and D. Hammett (Eds.), The Palgrave Handbook of International Development (pp. 55-76). London: Palgrave Macmillan UK.

-Drydyk, J. (2011). Development Ethics. In D. Chatterjee (Ed.), Encyclopedia of 
Global Justice (pp. 252-254). New York: Springer.

-Dower, N. (2008). The nature and scope of development ethics. Journal of Global Ethics, 10(2), 249-262.

-Escobar, A. (1984). Discourse and Power in Development: Michel Foucault and the Relevance of His Work to the Third World. Alternatives, 10(3), 377-400.

-Escobar, A. (1995). Encountering Development: The Making and Unmaking of the Third World. Princeton, NJ: Princeton University Press.

-Escobar, A. (2000). Beyond the Search for a Paradigm? Post-Development and beyond. Development, 43(4), 11-14.

-Escobar, A. (2007). 'Post-Development' as Concept and Social Practice. In A. Ziai (Ed.), Exploring Post-Development: Theory and Practice, Problems and Perspectives (pp. 18-31). London: Routledge.

-Esteva, G. (1985). Development: Metaphor, Myth, Threat. Development: Seeds of Change, 3, 78-79.

-Esteva, G. (1987). Regenerating People's Space. Alternatives, 12, 125-52.

-Esteva, G. and Prakash, M. S. (1998). Grassroots Post-Modernism: Remaking the Soil of Cultures. London: Zed Books.

-Esquith, S. and Gifford, F. (Eds.) (2010). Capabilities, power, and institutions: Toward a more critical development ethics. University Park, PA: Pennsylvania State University Press.

-Fieser, J. (2017) Ethics. The Internet Encyclopedia of Philosophy. Recovered from http://www.iep.utm.edu/ethics

-Gasper, D. (2004). The ethics of Development - From economism to human development. Edinburgh: Edinburgh University Press.

-Goulet, D. (1971). The Cruel Choice: A new concept in the theory of development. New York: Antheneum.

-Goulet, D. (1997). Development ethics: a new discipline. International Journal of Social Economics, 24(11), 1160-1171.

-Goulet, D. (1995). Development Ethics: A Guide to theory and practice. London: Zed books.

-Goulet, D. (2006). Development Ethics at work: Explorations - 1962 - 2002. Abingdo Oxon, UK, and New York: Routledge.

-Keleher, L. W. (2007). Empowerment and international development. Dissertation. Recovered from http://drum.lib.umd.edu/handle/1903/7584

-Keleher, L. (2014). Three and a Half Approaches to Development. National Endowment for the Humanities. Recovered from https://edsitement.neh.gov/

-Keleher, L. (2017). The Role of Philosophers in Development. In L. Keleher and J. Stacy (Eds.), Agency and Democracy in Development Ethics. Forthcoming, Cambridge University Press.

-Keleher, L. (2018). Integral Human Development. In J. Drydyk and L. Keleher (Eds.), Routledge Handbook to Development Ethics. Forthcoming, Francis and Taylor.

-Nussbaum, M. (1988). Nature, Function, and Capability: Aristotle on Political Distribution. In Oxford Studies in Ancient Philosophy: Supplementary Volume. Oxford University Press. 
-Nussbaum, M. (2001). Women and human development: The capabilities approach. Cambridge: Cambridge University Press.

-Nussbaum, M. (2011). Creating capabilities. Cambridge, Mass.: Harvard University Press.

-Schwenke, C. (2009). Reclaiming value in international development. Westport: Prager Publishers.

-Seers, D. (1969). The Meaning of Development. Paper presented at the Eleventh World Conference of the Society for International Development, New Delhi.

-Sen, A. (1979). Equality of What? Stanford University: Tanner Lectures on Human Values (Available from the Tanner Lectures website).

-Sen, A. (1985). Commodities and Capabilities. Amsterdam: North-Holland.

-Sen, A. (1999). Development as Freedom. New York: Oxford University Press.

-Streeten, P. (1994). Strategies for Human Development. Copenhagen: Handelshojskolens Forlag.

-Streenten, P. (1981). First Things First: Meeting Basic Human Needs in Developing Countries. Washington: Published for the World Bank, Oxford University Press.

-Wilber, C. K. \& Dutt, A. K. (2010). New directions in development ethics: Essays in honor of Denis Goulet. Notre Dame, IN: University of Notre Dame Press.

-Ziai, A. (2004). The Ambivalence of Post-Development: Between Reactionary Populism and Radical Democracy. Third World Quarterly, 25(6), 1045-1060.

-Ziai, A. (2007). Development Discourse and Its Critics: An Introduction to Post-Development. In A. Ziai (Ed.), Exploring Post-Development: Theory and Practice, Problems and Perspectives (pp. 3-17). London: Routledge.

-Ziai, A. (2013). The Discourse of 'Development' and Why the Concept Should Be Abandoned. Development in Practice, 23(1), 123-136.

Sumario: Introduction; 1. Development ethics: a very brief history; 2. Development ethics as ethical reflection on the ends and means of development; 3. Four levels of ethical reflection; 4. Integral human development; References. 